focus on German Studies.

https://journals.uc.edu/index.php/fogs

Issue 28 (2021)

Book Review

Dispossession: Plundering German Jewry, 1933-1953

By Christoph Kreuzmüller and Jonathan R. Zatlin (Eds.), University of Michigan

Press, 2020. 402 pp. $\$ 74.95$

Yu Huang

University of Waterloo/Universität Mannheim

How to Cite: Huang, Yu. “Book Review: Dispossession: Plundering German Jewry, 1933-1953”. focus on German Studies 28, no. 28, 2021, pp. 172-177. DOI: $10.34314 /$ FOGS2021.00009 


\section{Dispossession: Plundering German Jewry, 1933-1953}

\section{By Christoph Kreuzmüller and Jonathan R. Zatlin (Eds.), University of Michigan Press, 2020. 402 pp. $\$ 74.95$}

Yu Huang

Dispossession: Plundering German Jewry, 1933-1953 demonstrates the interrelation between possession, belonging, and identity of the Jewish population during the Nazi regime. In this historical documentation of the Jewish economic life during the Third Reich, scholars specialized in various fields (political history, social history, German history, Jewish studies, etc.) faithfully capture the nature of the economic propaganda and provide their readership with critical cultural interpretation and economic analysis of the German Jewry's deprivation. In so doing, the purpose of this edited volume is to investigate the influence of the Nazi policy toward Jewish economic life including Jews' properties, unemployment, everyday business, and market competition. Whereby, authors attempt to generate a broader question that concerns the relation between economic exploitation, the Nazi ideology, and antisemitism. In fourteen chapters, scholars with a diverse range of expertise examine the Jewish dispossession first on a macroeconomic scale and followed by specific sectors such as shoe shops, companies, daily business, and banks. The second part of the book undertakes the themes of the economic deprivation during wartime as well as its legacy and aftermath in postwar Germany. 
Despite a tremendous amount of research has been conducted on the Third Reich and the Holocaust, scholarship usually focuses on Jewish suffering during the genocide and the moral aspect of the mass murders of European Jews, as opposed to more structural concerns, such as the economic policy, that unveil the deeper motivation and rationale of the Nazi conscience. A moral reading of the Holocaust is inadequate and problematic insofar as it escalates and fetishizes the Nazis to a "privileged" position in history and does not register that Nazism itself is already a form of victimization in disguise. Fortunately, since the past fifteen years scholars have turned their attention to the Jewish economic life and started to consider more underlying factors that may play a crucial role in the Jewish question. Thus, this collection of essays adds a series of comprehensive and wide-ranging resources and analyses to the ongoing discourse by attempting to provide a possible answer of what antisemitism really is and the possible economical causes and contributors (and their related rationale) that might have provoked the genocide.

As a collected volume, how to connect and discern the material and information with different focuses and sometimes contrasting arguments is ultimately up to the readers. Overall, the volume successfully presents us with a broad range of critiques of Nazi policy. Both S. Jonathan Wiesen and Albrecht Ritschl call attention to the exaggeration of the Jewish affluence and Jewish stereotype that links to money, disputing the simplistic causal relationship between economy and the Holocaust. The following chapter by Christine Schoenmakers outlines a 
confiscatory agent, the German Gold Discount Bank, that plundered Jewish exporting businesses. Scholars interested in specific sectors would find chapters from Pamela Swett on shoe shops and Johannes Beermann-Schön on transportation particularly helpful, although the two authors have different standpoints on the motivation behind the dispossession of the Jewish businesses. Tal Bruttmann's chapter on dispossession in France and Christoph Kreutzmüller's chapter on dispossession in the Netherlands will offer an invaluable resource to scholars interested in the Nazi policy across Europe, such as the Nazi vision of the German hegemonic European economy. Due to space limitations, I will not outline or summarize the content of all fourteen chapters, especially since the introduction of the book already provides us with an exhaustive summary. For the remaining part of this book review, I will highlight two parts of the book that expressly demonstrate key themes and arguments.

The introduction written by Kreuzmüller and Jonathan R. Zatlin starts with a philosophical discussion of the conceptions of possession and dispossession, examining dispossession through the lens of belongings, and thereby arguing that dispossession is a priori a loss of cultural autonomy (2). The two editors not only cover the key historical events and snapshots of the Nazi policy against the Jewish properties but also critically point out that the exclusion of economic freedom is essentially an exclusion of the belonging to the Volk of the German Jewry (5), despite the distinction between Volk and Jewishness (“Aryan" and "nonAryan") remain unsettled and even obscure. In chapter one, Wiesen aptly argues that the 
economic assault of the German Jewry should be seen as a central strategy of the Nazi racial ideology as opposed to "an incidental byproduct of the Holocaust" (33). As such, Wiesen challenges the conventional reading of the Nazi motivation of the Holocaust, making the case that the Nazi's economic antisemitism created the most successful propaganda and belief: not only were Jews much more affluent than the so-called "Aryans" but also whoever was financially or materially connected to Jews "was a traitor to the nation" (36). Commercial morality is a method that the Nazis used to eliminate Jews from the customer economy and politics, thereby fulfilling the fantasy of achieving a state of racial purity. At this point, it is important to note that the purpose of the book is not to confirm the Jewish stereotype of money and wealth; quite on the contrary, the book critically argues against the stereotype by highlighting the ideological principles of Nazi Germany. Indeed, the best way to overcome stereotypes and prejudices is not to avoid or neglect their existence but precisely to confront them by addressing their core positions.

En masse, Dispossession: Plundering German Jewry, $1933-1953$ is a critical step towards the research on financial history and economic antisemitism. While a vast amount of recent research and publications on the Holocaust and the Third Reich tend to be reduced to cliches of victimization, this book displays a much-overlooked area of interest without excessive dogmatism or overt moralization. The wide array of aspects examined in the book can serve as a sample methodology for historians and students as a source of reference. To be sure, one 
message we should get from this book is that although the Nazi economic policy and the Jewish question should not be treated separately, there is no linear causality that one thing straightforwardly results in another. I believe this book successfully showcases that antisemitism is not simply a kind of hatred and antagonism towards Jews but it is a symptom that arises from a series of successful propaganda (which is not limited to the economical aspect). Dispossession is not just a matter of economy but a loss of cultural autonomy, and this loss is not exclusive to Jews. Thus, it is crucial for us to acknowledge that the event is not an unfortunate by-product of antisemitism and the event is not exceptional par excellence. Without identifying the symptoms and remembrance, it is an event that could be repeated and could happen again. 